\title{
Soybean: Food or Remedy?
}

\author{
Barbalho, Sandra Maria1,2 and Farinazzi-Machado, Flávia, M. V.2 \\ ${ }^{1}$ Faculty of Food Technology - FATEC Marília \\ ${ }^{2}$ University of Marilia - UNIMAR \\ Brazil
}

\section{Introduction}

The soybean plant (Glycine max L) belongs to the family Leguminosae (Order Rosacea) and probably originated from China, 4000 to 5000 years ago. It was introduced in Europe circa 1700 and today is one of the world's most important crops. It is an important plant for human and animal nutrition as well as for industrial purposes because about $60 \%$ of the world's processed food products contain ingredients derived from soy (Liu, 1999; Friedman \& Brandom, 2001; Soares et al., 2005; Priolli et al., 2002).

Soybean is an almost unique food because of its protein, mineral and fiber content. In the plant kingdom it has the highest content of phytochemicals (such as flavones), which are compounds whose structure closely resembles that of estrogen, suggesting that it could exert similar activities (Lissin \& Cooke, 2000; Mateos-Aparicio et al., 2008).

The processing cost of soybean oil is very low. In addition to oil, soybeans are processed into many foods and food additives such as lecithin (Gesteira et al., 2003; Mateos-Aparicio et al., 2008). Lecithin is widely used as a functional food and for industrial applications due to its emulsifying properties (Awazuhara et al., 1998; Taylor \& Kabourek, 2003).

The soybean plant has oblong pods with 2 to 4 seeds containing approximately $38 \%$ protein, $18 \%$ oil, $30 \%$ carbohydrates, $14 \%$ moisture, ash, and secondary components and it is an important source of vitamins (A, thiamin, riboflavin, pyridoxine and folic acid) and minerals (Fe, Zn, Mg, K, Ca, Mn, and Se), phytoestrogens and fibers (Liu; 1997b; Anderson et al., 1995; Soares et al., 2005; Reynolds et al., 2006).

Soy concentrates and isolates provide highly concentrated protein sources, high lysine content, a bland flavor, and reduction in flatulence factors and reducing sugars, and they may improve the overall quality of products (Singh et al, 2008). Soy protein is low in viscosity; therefore, it can be used in beverage applications (Xie \& Hettiarachchy, 1997; Jasentuliyana et al., 1998), helping to achieve the desired mouth-feel. The viscosity promoted by soy isolate makes it ideal for other nutritious liquid products such as infant formulas, creamers, milk replacers, and spray-dried products (Yao et al., 1988; Riaz, 1999). Textured soy flour is also known as TPS (textured soy protein) or TVP (textured vegetable protein) (Endres, 2001). Textured protein products are prepared commercially by thermoplastic extrusion of flours, grits, and protein concentrates under heat and pressure to form chips, chunks, flakes, and a variety of other shapes (Singh et al, 2008; Mesa et al., 2009). TPSs are frequently made to resemble beef, pork, seafood, or poultry in structure and appearance when hydrated (Endres, 2001; Macedo-Silva et al., 2001). 
Despite its advantages, the soybean possesses antinutritional factors such as protease inhibitors, which inhibit proteolytic enzymes and decrease food digestion. These factors can reduce the bioavailability of the proteins ingested by the organism (Miura et al., 2001; Moughan, 2003; Monteiro et al., 2003).

Soybeans and soy foods have been recognized for their low fats and good quality protein. The soybean proteins, fibers and phytoestrogens are known to decrease cholesterol levels and to produce positive effects in reducing chronic disease risk such as diabetes, obesity and vascular diseases (Allison et al., 2003; Martin et al., 2008; Jimenez-Escrig et al., 2008; Messina, 2010; Chen et al., 2010; Kang et al, 2010). Since the 1960s, soybean protein products have been used as nutritional or functional food ingredients in every food group available to the consumer (Endres, 2001). In Asia, soy proteins have been used for human consumption for centuries, during which various unique soy protein foods have been established. Onuegbu et al. (2011) studied the effect of soymilk on the lipid and lipoprotein profile of normocholesterolemic men and found that the consumption of $500 \mathrm{~mL}$ of this drink can decrease cholesterol and triglycerides levels and increase HDL-c levels.

Bansai \& Parle (2010) observed that, due to its proestrogenic, antioxidant and neuroprotective properties, soybeans can be used as a remedy to improve memory and to manage cognitive deficits. Moreover, soy and soy products provide an alternative source of protein for people with cow milk protein intolerance (Riaz, 1999; Dupont et al., 2010) and an alternative to the use of probiotics. Supplementation with prebiotics enhances the potential of soymilk as a carrier for probiotics (Yeo \& Liong, 2010).

\section{Protein composition}

Proteins are essential for the growth and maintenance of corporal structures. Vegetable proteins usually affect protein nutrition because they are not complete in essential amino acids, thus reducing the quality of the protein. Animal proteins are considered complete because they contain all the amino acids required to produce the human body proteins (Martínez Augustin \& Martínez de Victoria, 2006).

The protein content of soybean is about $40 \%$ and it is equivalent to animal proteins. Soybean has a protein content of about $40 \%$, which is equivalent to animal proteins. The most significant limiting amino acids are methionine $(10 \mathrm{mg} / \mathrm{g}$ protein) and cystine $(25.00)$, which are sulfur-containing amino acids, but soy is rich in lysine $(68.37 \mathrm{~g} / \mathrm{mg}$ protein) (Chung et al., 1996; Sacks et al., 2006; Mateos-Aparicio et al., 2008). Liu (1997b) reported that soybean has the following amino acids content in milligrams per gram of protein: arginine (77.16), alanine (40.23), aspartic acid (68.86), glutamic acid (190.16), glycine (36.72), histidine (34.38), isoleucine (51.58), leucine (81.69), lysine (68.37), phenylalanine (56.29), proline (52.92), serine (54.05), threonine (41.94), tryptophan (12.73), tyrosine (41.55) and valine (41.55).

The presence of antinutritional factors such as proteolytic enzymes, trypsin inhibitors, phenolic compounds and phytic acid can reduce the quality of proteins and their use in the organism (Liu, 1999; Monteiro et al., 2003).

Animal proteins are almost always related to high levels of saturated fats. This is not the case of soy proteins, which are rich in essential amino acids, making them suitable to substitute animal protein sources. Soy proteins can also partly replace other sources of calories such as fats and carbohydrates (Sacks et al., 2006; Mateos-Aparicio et al., 2008).

Soy protein ingredients are used in compound foods for their functional properties, including water and fat absorption, emulsification, aeration (whipping) and heat setting and 
for increasing total protein content and improving the essential amino acids profile (Jasentuliyana et al., 1998).

\subsection{Soy protein and health}

The high content of fats in the proteins of several animal species can be implicated in the increase of blood cholesterol, triglycerides and LDL-c (low density lipoprotein). The widespread concern about vascular disease (associated with the daily ingestion of fats and sugars) has motivated numerous studies on soybean protein (Allison et al., 2003; Sacks et al., 2006; Martin et al., 2008; Messina, 2010; Bermudez et al., 2010). Maki et al. (2010) studied the effects of the consumption of soy protein on subjects with hypercholesterolemia and concluded that it can reduce total blood cholesterol, LDL-c and triglycerides levels. Lerman et al. (2010) studied the effects of a diet containing soy protein and sterols in adults with metabolic syndrome and observed improvements in their total levels of cholesterol, LDL-c and triglycerides, as well as HDL-c. Metabolic syndrome can be characterized by low HDL$c$ and high total cholesterol and triglycerides and is associated with increased risk of cardiovascular disease and death, which is significantly increased when accompanied by elevated low-density lipoprotein cholesterol (LDL-c). Their study led these authors to conclude that individuals at high cardiovascular risk benefit from a soy/phytosterolcontaining medical food. In addition, Torre-Villalvazo et al. (2009) showed that dietary soy protein can reduce the ceramide concentration in the heart and may be considered a dietary therapeutic approach for the prevention of lipotoxic cardiomyopathy.

Because of its protein content, soy has gained attention for its potential role in improving risk factors for cardiovascular disease, which is one of the leading causes of death worldwide. In 1999, the FDA (US Food and Drug Administration) approved labeling for foods containing soy protein as a protection against coronary heart disease. Soybean's potential to reduce total cholesterol and LDL-c and increase HDL-c (high density lipoprotein) was observed in epidemiological studies on diet and vascular disease in Japan and other Asian countries that consume large amounts of soybeans. These studies revealed that these countries had lower heart disease rates (Reinolds et al., 2006; Lukaczer et al., 2006; Hirayama et al., 2010).

Soy proteins can also produce beneficial effects on the activity of the angiotensin converting enzyme (ACE). They act as ACE inhibitor peptides that can be released enzymatically from precursor proteins in vitro during food processing and in vivo during gastrointestinal digestion. These peptides can reduce blood pressure by limiting the vasoconstrictive effects of angiotensin II and potentiating the vasodilatory effects of bradykinin (De Leo et al., 2009). Results of epidemiological and animal studies suggest that consuming soy-containing diets reduces the incidence of certain types of cancer. Some authors have shown that soy protein isolate may protect against cancer via multiple mechanisms, including: 1) increased mammary gland differentiation, 2) decreased activation of procarcinogens to carcinogens, and 3) regulation of genes in signal transduction pathways underlying tumor initiation, promotion and/or progression (Badger et al, 2005).

Proteins have a higher satiety power than carbohydrates and fats. Studies suggest that this effect can be attributed to a higher thermogenic response of protein. Soy protein may have an important effect on postprandial energy expenditure compared to animal protein preparations and this can reduce ingestion and obesity, which is a risk factor for heart disease (Jequier, 2002; Paddon-Jones et al., 2008; Alfenas et al., 2010). 
Trevisan et al. (2010) showed that the ingestion of soy protein can help increase the resting energy expenditure of post-menopausal women who practice exercises.

\section{Carbohydrate composition}

Soybeans are also rich in carbohydrates, which represent approximately 35\% of their compounds. They contain about $1 \%$ of starch and non-starch polysaccharides such as cellulose, hemicelluloses and pectic polysaccharides. Their main sugars are arabinose, galactose, uronic acids and glucose (cellulose) (Sosulsk et al., 1982; Wilcox \& Shibles, 2001; Espinosa-Martos \& Ruperes, 2006; Redondo-Cuenca et al., 2007).

\subsection{Soy carbohydrates and health}

Soybeans are a rich source of raffinose, a family of oligosaccharides such as a-galactosides or galactooligosaccharides, which are non-digestible carbohydrates. Human beings do not have a-galactosidase, which is needed to hydrolyze these molecules, so they cannot be digested. These molecules are digested by beneficial bifidogenic microorganisms which produce gases and short chain fatty acids that have prebiotic activity (functional effects).

Soybeans also contain sucrose in the form of low amounts of the monosaccharides fructose, rhamnose and arabinose. Significant levels of glucose occur only in immature seeds. Nondigestible oligosaccharides, one of the most popular components of functional food, are related to many health benefits (Tomomatsu; 1994; Crittenden \& Playne, 1996; Torres y Torres et al., 2006). Monosaccharides such as glucose and arabinose, and measurable amounts of di- and oligosaccharides with sucrose, raffinose, and stachyose can be found in soybean soluble carbohydrates (Liu, 1999; Sosulski et al., 1982; Huisman, 2000; MateosAparicio et al., 2008).

The amount of fibers in soybean can reduce blood cholesterol levels and insulin resistance in diabetics. These effects can reduce the incidence of cardiovascular disease and death (Chandalia et al., 2000; Redondo-Cuenca et al., 2007; Reynolds et al., 2006; Chen et al., 2010). Fibers in diet can also produce anti-inflammatory and anti-carcinogenic effects (Scheppach et al., 2004).

\section{Lipids composition}

Liu (1999) found that soybean contains about $22 \%$ of oil. The fractions contain triglycerides (about 99\%) and other components such as phospholipids, unsaponifiable matter (tocopherols, phytosterols and carbohydrates) and free fatty acids (Mateo-Aparicio et al., 2008).

Soybean contains high percentages of functional polyunsaturated fatty acids, as well as $54 \%$ linoleic acid and 4-5\% linolenic acid, considerable percentages of oleic acid (22-25\%) and moderate percentages of saturated fatty acids such as palmitic $(11 \%)$ and stearic acids $(4 \%)$. The predominant fatty acid in soybeans is linoleic acid, which accounts for approximately $54 \%$ of their total fatty acid content (Martins et al., 2003). There are few good sources of -3 fatty acids such as linolenic acid. Available data suggest that many people have a diet poor in this acid; hence, soybeans could be a good source to increase the intake of linolenic acid (Messina, 1997; Martin et al., 2008).

Refined soybean oil is the most widely consumed cooking oil in many countries. Its refining process includes degumming, neutralization, bleaching and deodorization steps. The 
isomerization reactions carried out during these steps may reduce alpha-linolenic acid levels significantly. The high temperatures employed in processing increase the rate of isomerization reactions, giving rise to increased trans fatty acid levels that may vary from 0.8 to $2.6 \%$ of the product's total fatty acids and comprise 18:1, 18:2, and 18:3 isomers (Martin et al., 2008).

Trans isomers of monounsaturated and polyunsaturated fat acids are implicated in negative effects on human health, such as reduction of cell membrane fluidity, increase in LDL-c and decrease in HDL-c levels, modifications in prostaglandin metabolism, and changes in platelet aggregation and vascular function. Many authors have demonstrated that the consumption of trans fats from partially hydrogenated fats may be associated with the development of coronary heart disease (Valenzuela \& Morgado, 1999; Oomen et al., 2001; Fernandez-San, 2009).

\subsection{Soy lipids and health}

The functional and nutritional value of vegetable oils is based in their fatty acid composition. Linolenic acid, with three double bonds, is extremely susceptible to oxidation (Gesteira et al., 2003). Omega polyunsaturated fatty acids are well known for their role in many physiological functions and seem to reduce risks of cardiovascular diseases. Several mechanisms have been proposed to explain the cardioprotective effect of W-3 PUF, including antiarrhythmic, hypolipidemic, and antithrombotic roles (Harper \& Jacobson, 2001; Holguin et al., 2004). These fatty acids may also have beneficial effects on pancreatitis, arthritis, allergy and inflammatory diseases (Seki et al., 2010; Lund et al., 2010; Persson \& Uller, 2010). They can modulate the anti-inflammatory process inside the blood vessels, changing the composition of the atherosclerotic plaque and reducing its rupture, which precedes infarction (Tull et al., 2009).

Burghardt et al. (2010) demonstrated the effects of dietary ratios of omega-3 (n-3) to omega-6 (n-6) polyunsaturated fatty acids (PUFAs) in controlling the markers of metabolic syndrome, including insulin sensitivity, inflammation, lipid profiles and adiposity. N-3 polyunsaturated fatty acids ( $n-3$ PUFAs) reduce plasma triacylglycerols and improve the lipoprotein profile by decreasing the fraction of atherogenic small dense LDL (Carpentier et al., 2006) and serum cholesterol levels (Chandrashekar et al., 2010). High stearic acid soybean oil is a trans-free, oxidatively stable, non-LDL-cholesterol-raising oil that can be used to replace trans fatty acids in solid fat applications. In comparison with other saturated fatty acids, stearic acid lowers LDL cholesterol and is neutral with respect to HDL cholesterol (Hunter et al., 2010). Lemke et al. (2010) showed that stearidonic acid-enriched soybean oil increases the omega-3 index by raising erythrocyte eicosapentaenoic acid concentrations, suggesting that it may contribute to cardiovascular protective effects.

Studies correlate the role of n-3 PUFA in the beneficial effects on obesity, insulin resistance and secretion of bioactive adipokines including leptin, adiponectin and visfatin (MorenoAliaga et al., 2010).

Omega-3 fatty acids seem to have a small, dose-dependent hypotensive effect, the extent of which seems to be dependent on the degree of hypertension, with a greater effect in hypertensive patients and those with high-normal blood pressure (Kris-Etherton et al., 2003; Mori, 2010).

Supplementation of human diets with omega-3 fatty acids reduced several aspects of neutrophil, monocyte, and lymphocyte functions, including the production of inflammatory mediators (Kelley, 2001). N-3 PUFAs inhibit inflammatory signaling pathways (nuclear 
factor-kappa B activity), down-regulate fatty acid (FA) synthesis and gene expression (sterol regulatory element binding protein-1c) and up-regulate gene expression involved in FA oxidation (peroxisome proliferator-activated receptor alpha) (Adkins \& Kellen, 2010).

\section{Isoflavones}

Isoflavones, which are phenolic compounds that belong to the phytochemicals, are called phytoestrogens in soybeans because they exhibit estrogenic effects. They belong to a group called flavonoids, whose structure consists of a flavone nucleus with two benzene rings linked to heterocyclic pyrane. In the plant kingdom, soy contains the largest amount of isoflavones (Setchell \& Cassidy, 1999; Carrão-Panizzi et al., 2002; Cederroth \& Nef, 2009).

The chemical structure of these phenolic compounds is similar to that of cholesterol except for the presence of an extra methyl or ethyl group. However, plant sterols are much less absorbed in humans than cholesterol (Abumweis \& Jone, 2008). Isoflavones are found mostly in soybeans in the form of B-glucoside conjugates, which include daidzin, genistin, glycitin and their malonyl and acetyl derivatives. Genistein and daidzein are the primary isoflavones in soybean. Isoflavone glucosides, which are hydrolyzed by intestinal microflora glycosidases, are released in the form of daidzein, genistein and glycitein aglucones: the bglycosides daidzin, genistin, and glycitin; the acetyl-b-glycosides 6"-O-acetyl-b-daidzin, 6"O-acetyl-b-genistin, 6"-O-acetyl-b-glycitin; and the malonyl-b-glycosides 6"-O-malonyl-bdaidzin, 6"-O-malonyl-b-genistin, and 6"-O-malonyl-b-glycitin (Genoveze et al., 2006; Torrezan et al., 2008). Isoflavones are non-nutritive substances that may be related to beneficial health effects (Sacks et al., 2006; Carrara et al., 2009).

Soybeans are known to be rich in isoflavones, making them important components of human diet. The content of these compounds in different cultivars and different soy products may be variable. However, studies have shown that soybean processing causes a loss of isoflavones, e.g., in tofu: a 38\% loss in normal soybean tofu, $31 \%$ in bleached soybean tofu, and 56\% in lipoxygenase-free tofu (Ciabotti et al., 2006; Mateos-Aparicio et al., 2008).

\subsection{Soy isoflavones and health}

The use of soybeans in human diet can be associated with a reduction in health problems involving the risk of several chronic diseases such as diabetes, obesity, coronary heart disease, osteoporosis, and breast and prostate cancer (Brouns, 2002; Jenkins et al., 2003; Sacks et al., 2006; Mateos-Aparicio et al., 2008; Rajasree et al., 2009; Dong \& Qin, 2011).

\subsubsection{Soy isoflavones and menopause}

Soy is widely employed to treat menopausal symptoms and its use has been studied in cross-cultural comparisons. These studies have shown that women living in countries where large amounts of soy are normally consumed (e.g., Japan) have fewer menopausal symptoms and lower rates of coronary heart disease, fractures, and uterine or breast cancer than women living in countries where soy is not part of the normal diet (e.g., the United States and Western Europe) (Adlercreutz et al., 1992; Oddens, 1994; Vitolins et al., 2010; Cho et al., 2010).

Soybean isoflavones are believed to be beneficial for menopausal women because this phase is characterized by suppression of ovarian function and decreased estrogen secretion, with consequent morphological and metabolic disorders resulting from hormonal decline (Setchell \& Cassidy, 1999; Kang et al., 2010). 
The daily ingestion of soybean and its isoflavones reduces the frequency of hot flashes. It is possible that these isoflavones can bind to free estrogen receptors and produce a weak estrogenic effect. This could be useful as a dietary alternative or supplement in postmenopausal hormone replacement therapy (Cancelo-Hidalgo \& Castelo-Branco, 2010). The consumption of soybean isoflavones can also improve lipid profiles in postmenopausal women and contribute to reduce the risk of coronary heart disease (Merz-Demlow et al., 2000; Wangen et al., 2001; Nikander et al., 2004). Carmignani et al. (2010) evaluated the effects of dietary soy supplementation and concluded that it may be an effective alternative therapy for somatic and urogenital symptoms of menopause.

Soy isoflavones can also improve mood, vasomotor and other symptoms of menopause (Chedraui et al., 2010; Vitolins et al., 2010). Some authors have demonstrated the effects of soy isoflavones on of immune and oxidative stress markers in postmenopausal women (Ryan-Borchers et al, 2006).

The use of isoflavones also can be beneficial for postmenopausal women suffering from insomnia. In a study on postmenopausal women who took isoflavones for four months, Hachul et al. (2010) found a decrease in the intensity and number of hot flashes and reduced symptoms of insomnia (data confirmed by increased sleep efficiency, which was observed in a polysomnographic analysis).

\subsubsection{Soy isoflavones and heart disease}

Current guidelines recommend diet as the most effective way to prevent dyslipidemias, and some studies indicate that a plant-based diet is more effective in increasing blood lipid levels. The American Diabetes Association considers that a plant-based diet is healthful, nutritionally adequate, and may provide health benefits for the prevention and treatment of certain diseases (Ferdowsian \& Barnard, 2009; Craig \& Mangels, 2009).

Numerous epidemiological studies suggest that the regular ingestion of flavonoids can reduce the risk of many pathological conditions such as hypertension, diabetes, coronary heart disease, stroke and dementia (Ghosh \& Schhepens, 2009). Sagara et al. (2004) observed significant reductions in systolic and diastolic blood pressure, total cholesterol and non-high density lipoprotein cholesterol (non-HDL-C) in a group treated with a daily diet of $20 \mathrm{~g}$ of soy protein and $80 \mathrm{mg}$ of isoflavones. In their review, Taku et al. (2010) reported that a daily ingestion of 25-375 mg of soy isoflavones (aglycone equivalents) for 2-24 weeks significantly decreased systolic blood pressure by $1.92 \mathrm{mmHg}$ compared with placebo in adults with normal blood pressure and prehypertension.

The main objective in the treatment of heart diseases with isoflavones is to decrease LDL-c because it is the most common cardiac risk factor (Nagarajan, 2010).

Soybean-based diets have been reported to prevent cardiac events such as atherosclerosis. This condition is traditionally associated with obesity, insulin resistance, diabetes, dyslipidemia and inflammatory processes. The latter condition is considered the main factor for the initiation and progression of atherosclerosis. Dyslipidemia by itself is a primary risk factor for cardiovascular disease, peripheral vascular disease, and stroke. Soy-based diets can decrease all these risk factors because of their protein and flavonoids content (Jenkins et al., 2002; Kreijkamp-Kaspers et al., 2004; Sacks et al., 2006; Abumweis \& Jone, 2008; Wong et al., 2010; Nagarajan, 2010; Shukla et al., 2010).

Many studies have shown that isoflavones only affect the lipid profile when consumed in the presence of soy protein. Greaves et al. (1999) showed that monkeys responded to 
isoflavonoids only if they also received soy protein. Probably these proteins facilitate the transport of isoflavonoids in the blood or their entry into target organs such as liver or muscle cells (Mikkola et al., 2003; Nikander et al., 2004).

Hyperglycemia is implicated in many vascular complications because it is related to oxidative stress and endothelial dysfunction. Soy isoflavones (genistein and daidzein) can protect the cells against hydrogen peroxide-induced apoptosis and promote inhibition of cell proliferation due to oxidative stress (Xu et al., 2009).

Although isoflavone activity has been linked to atheroprotective effects, it has been increasingly accepted that isoflavones may activate other nuclear receptors regulating lipid metabolism, such as liver $\mathrm{x}$ receptor, farnesoid $\mathrm{x}$ receptor and peroxisome proliferatoractivated receptors (PPARs). PPARs, which are members of the nuclear hormone receptor superfamily of ligand-activated transcription factors, regulate the expression of target genes involved in several physiological processes such as lipid catabolism. This explains their hypolipidemic effects and glucose because they increase insulin sensitivity. This would be useful in the treatment of type 2 diabetes (Ricketts et al., 2005; Carrara et al., 2009).

\subsubsection{Soy Isoflavones and bones}

Osteoporosis involves the reduction of bone mass, leading to enhanced bone fragility and increased risk of fractures. This condition can affect postmenopausal women because the ovaries stop producing estrogens. The treatment for osteoporosis is long and therapeutics may also causeside effects (Bitto et al., 2010).

Osteoporosis is a skeletal disorder that predisposes to fractures. Postmenopausal women are susceptible to this condition because they go through a rapid phase of bone loss. This is preceded by declining concentrations of circulating estrogen, which plays an important role in maintaining the integrity of bone density by regulating bone formation and resorption. The intake of soybean isoflavones can help prevent the symptoms caused by loss of estrogen. Asian women are at lower risk of osteoporosis than Western women, which can be explained by the soybean-rich diet in Asian countries (Setchell \& Cassidy, 1999; Nilsson \& Gustafsson, 2002; Bawa, 2010).

The use of soybeans or isoflavone supplement foods may increase bone mass. The intake of genistein aglycone stimulates osteoblast and inhibits osteoclast function, preventing bone loss, and daidzein has been shown to increase bone mass in postmenopausal women. Soy isoflavone extract supplements increase lumbar spine bone mineral density in menopausal women (Kreijkamp-Kaspers et al., 2004; Bitto et al., 2010; Taku et al., 2010; Hooshmand et al., 2010; Bawa, 2010). Yamori et al. (2002) studied forty healthy female postmenopausal Japanese immigrants living in Brazil and found that urinary excretion of bone resorption markers was reduced in the isoflavone-treated group (37.3 $\mathrm{mg}$ per day for 10 weeks), while the placebo group showed no significant reduction. Differences in levels of urinary isoflavones and bone resorption markers between the two groups were significant.

In addition, studies have shown that soy can also be applied clinically to substitute calcium phosphate cements on bone regeneration. Perut et al. (2010) describe the osteoblastic response to injectable bone cement based on a composite formulation including bioactive soybean and gelatin foaming agents. They took advantage of the foam-forming capacity of defatted soybean and gelatin gels to establish porosity and aid in osteoblast adhesion and growth, suggesting that the use of this bioactive compound can help bone regeneration through less invasive surgery. 


\subsubsection{Soy isoflavones and cancer}

Many studies have suggested that the use of soybeans in the regular diet can reduce levels of different cancers (Mateos-Aparicio et al., 2008; Liss et al., 2010). The consumption of soybeans can prevent prostate cancer through the anti-androgenic effects of isoflavones (Liss et al., 2010).

Oncology research has focused much attention on genistein (isoflavones found in soy and soy products) because it exerts a wide range of biological effects. Several epidemiological studies suggest that genistein is able to inhibit growth of primary tumors, which is the critical first step in the progression of metastatic disease. It can inhibit the development of metastatic disease in a variety of cancer types and inhibit cellular proliferation. It also increases the rate of cancer cell death, called apoptosis, and decreases the rate of cancer cell migration, which is important in the metastatic cascade (Pavese et al., 2010).

The use of soy isoflavones and its benefits for women with breast cancer has become a subject of public consensus. Dong \& Qin (2011) observed that the consumption of soy isoflavones is associated with a significantly reduced risk of breast cancer incidence in Asian populations and is inversely associated with risk of breast cancer recurrence. Kang et al. (2010) reported that the intake of soy isoflavones is related to a lower risk of recurrence among postmenopausal breast cancer patients.

Soybean intake may be related to lower risk of developing breast cancer due to the presence of genistein (Cho et al., 2010). This isoflavone is a tyrosine kinase inhibitor and agonist of estrogen receptor- $\beta$, which is known to have antitumor properties. Lattrich et al. (2010) showed that genistein can enhance the antitumor activity of trastuzumab (a common therapy for women with breast cancer whose tumors have excessive HER2 protein) in breast cancer cells in vitro.

Genistein also may exert cytotoxic activity against breast cancer cells. This mechanism possibly involves mobilization of endogenous copper, whose levels are considerably increased in many types of cancers. Ullah et al. (2010) showed that this isoflavone can target endogenous copper, leading to prooxidant signaling and consequent cell death. The authors of this study attribute the anticancer effect of genistein to its preferential cytotoxicity towards cancer cells.

In addition to the above, the antioxidant and anti-inflammatory effects of genistein can protect normal tissues from the adverse effects of chemotherapy and radiation and can be helpful in ameliorating the side effects of chemotherapy (Tacyildiz et al., 2010).

\subsubsection{Soy isoflavones and blood pressure}

Arterial hypertension is related to vascular disease and death. Nevertheless, some factors are associated with the improvement of this condition. Soy products can reduce blood pressure. Longitudinal and clinical studies have shown that soy protein and isoflavones play an important role in diastolic blood pressure. The following mechanisms may explain the effects of soy protein and isoflavones on blood pressure: 1) improvement of systemic arterial compliance, 2) a natriuretic effect similar to the commonly used drug furosemide, 3) amino acid composition, and 4) lower salt retention. Soy protein and isoflavones also increase nitric oxide levels. This substance plays an effective role in regulating blood pressure and its increase is associated with the reduction of blood pressure via vasodilatory effects (Gimenez et al., 1998; Woodman et al., 2002; Nyby et al., 2004; Yang et al., 2005; Hermann et al., 2006; Taku et al., 2007; Azadbakht et al., 2007; Simão et al., 2010; Galleano et al., 2010). 


\section{Soy-derived phosphatidylserine and memory function}

A gradual decline in cognitive function is very common with aging. Many neurochemical substances are associated with functional neuronal membrane and memory. Alterations in these substances and in their mechanisms of action are related to a decline in cognitive functions. Many studies have demonstrated the important role of phosphatidylserine in reducing and reversing age-related neurochemical damage in non-demented people with memory impairment and in some diseases (Ritcher et al., 2010).

Phosphatidylserine, an abundant phospholipid in the brain, can be extracted from bovine cortex to help improve the cognitive function of the elderly, including Alzheimer's patients. However, the use of bovine cortex may be unfeasible due to the minuscule quantity obtained from each animal and the risk of bovine spongiform encephalopathy. This fact emphasizes the importance of soy-derived phosphatidylserine (soybeans are used to produce soy-derived phosphatidylserine, which is produced from lecithin by an enzymatic reaction with L-serine). Kato-Kataoka et al. (2010) reported improvements in neuropsychological test scores and in memory ability in their test subjects treated with phosphatidylserine. These subjects were 50 to 69 -year-old Japanese men and women suffering from subjective memory impairment. After six months of treatment, the authors found that soy-derived phosphatidylserine is a safety food ingredient that can improve memory functions in the elderly with impaired memory and can be useful as a supplement to prevent the development of dementia in men and women suffering from memory impairment (Amaducci, 1988; Zanotti et al., 1989; Engel et al., 1992; Vakhapova et al., 2010; Kato-Kataoka et al., 2010).

\section{Conclusions}

Soybeans represent an alternative food that is easy to consume while simultaneously possessing functional properties. They can be used as additives in new food products such as soy protein concentrates and soy protein isolates, soy milk, yogurt and tofu, grist, soybean flour, breads, crackers, cookies, breakfast cereals, diet supplements and textured soy protein used in meat products.

Furthermore, soy can be used as a functional food. It has an important protective effect against many chronic diseases because of its content of bioactive components, whose characteristics are beneficial for nutritional physiology and metabolism. Soy protein, isoflavones (phytoestrogens), non-digestible carbohydrates, and omega polyunsaturated fatty acids have gained considerable attention for their potential role in reducing the risk factors for cardiovascular disease, the incidence of certain cancers, inflammatory diseases, diabetes, osteoporosis and other disorders attributed to modern life styles and food habits, which have been confirmed by epidemiological and clinical studies.

In view of the above, it can be concluded that soybeans have multiple effects on human health and well-being, both as food and as remedy.

\section{References}

AbuMweis, S. S. \& Jones, P. J. (2008). Cholesterol-lowering effect of plant sterols. Current Atherosclerosis Reports. Vol.10, No.6, (December 2008), pp. 467-72, ISSN 1534-6242 
Adkins, Y. \& Kelley, D. S. (2010). Mechanisms underlying the cardioprotective effects of omega-3 polyunsaturated fatty acids. The Journal of Nutritional Biochemistry, Vol.21, No.9, (May 2010), pp.781-92, ISSN 1873-4847

Adlercreutz, H.; Hamalainen, E.; Gorbach, S. \& Goldin, B. (1992). Dietary phytooestrogens and the menopause in Japan. Lancet.Vol.339, No.1233, (May 1992), pp. 56-78, ISSN 1474-547X

Alfenas, R. C. G.; Bressan, J. \& Paiva, A. C. (2010). Effects of protein quality on appetite and energy metabolism in normal weight subjects. Arquivos Brasileiros de Endocrinologia e Metabologia, Vol.54, No.1, (February, 2010), pp. 45-51, ISSN 1677-9487

Allison, D. B.; Gadbury, G.; Schwartz, L. G.; Murugesan, R.; Kraker, J. L.; Henshka, S.; Fontaine, K. R. \& Heymsfield, S. B. (2003). A novel soy-based meal replacement formula for weight loss among obese individuals: a randomized controlled clinical trial. European Journal of Clinical Nutrition, Vol.57, No.4, (April 2003), pp. 514-522, ISSN 1476-5640.

Amaducci, L. (1988). The SMID group Phosphatidylserine in the treatment of Alzheimer's disease: results of a multicenter study. Psychopharmacology Bulletin, Vol.24, No.1, (1988), pp. 130-134, ISSN 0048-5764

Anderson, J. W.; Johnstone, B. M. \& Cook-Newell, M. E. Meta-analysis of the effects of soy protein intake on serum lipids. The New England Journal of Medicine, Vol.333, No.5, (August 1995), pp. 276-82, ISSN 1533-4406

Awazuhara, H.; Kawai, H.; Baba, M.; Matsui, T. \& Kamiyama, A. (1998). Antigenicity of the proteins in soy lecithin and soy oil in soybean allergy. Clinical and Experimental Allergy. Vol.28, No.12, (December 1998), pp.1559-1564, ISSN 1365-2222

Azadbakht, L.; Kimiagar, M. \& Mehrabi Y. (2007). Soy inclusion in the diet improves features of the metabolic syndrome: a randomized crossover study in postmenopausal women. American Journal of Clinical Nutrition, Vol.85, No.3, (March 2007), pp. 735-41, ISSN 1938-3207

Badger, T. M.; Ronis, M. J. J.; Simmen, R. C. M. \& Simmen, F. A. (2005). Soy Protein Isolate and Protection Against Cancer. Journal of the American College of Nutrition, Vol.24, No.2, (April 2005), pp.146S-149S, ISSN 1541-1087

Bansal, N. \& Parle, M. (2010). Soybean supplementation helps reverse age- and scopolamine-induced memory deficits in mice. Journal of Medicinal Food, Vol.13, No.6, (December 2010), pp. 1293-300, ISSN 1096-620X

Bawa, S. (2010). The significance of soy protein and soy bioactive compounds in the prophylaxis and treatment of osteoporosis. Journal of Osteoporosis, Vol.8, (March 2010), in press. ISSN 891058.

Bermúdez, V.; Arráiz, N.; Aparicio, D.; Rojas, E.; Gotera, D.; Guerra, X.; Canelón, R.; Faría, J.; Sorell, L.; Amell, A.; Reyna, N.; Cabrera, M.; Mengual, E.; Cano, R.; Cano, C. \& Velasco, M. (2010). Lipoprotein(a): from molecules to therapeutics. American Journal of Therapeutics, Vol.17, No.3, (May-June, 2010), pp. 263-73. ISSN 1536-3686

Bitto, A.; Polito, F.; Squadrito, F.; Marini, H.; D'Anna, R.; Irrera, N.; Minutoli, L.; Granese, R. \& Altavilla, D. (2010). Genistein aglycone: a dual mode of action anti-osteoporotic soy isoflavone rebalancing bone turnover towards bone formation. Current Medicinal Chemistry. Vol.17, No.27, (2010), pp. 3007-18, ISSN 1875-533X 
Brouns, F. (2002). Soybean isoflavones: a new and promising ingredient for the health foods sector. Food Research International, Vol. 35, No.2-3, (2002), pp.187-193, ISSN 09639969.

Burghardt, P. R.; Kemmerer, E. S.; Buck, B. J.; Osetek, A. J., Yan, C.; Koch, L. G., Britton, S. L. \& Evans, S. J. (2010). Dietary n-3:n-6 fatty acid ratios differentially influence hormonal signature in a rodent model of metabolic syndrome relative to healthy controls. Nutrition $\mathcal{E}$ Metabolism, Vol.7, No.53, (June 2010), 8 pages, ISSN 1743-7075.

Cancelo-Hidalgo, M. J. \& Castelo-Branco, C. (2010). Optimizing soy isoflavones effect in postmenopausal women: the impact of timing on climacteric symptoms. Gynecological Endocrinology, (October 2010), in press, ISSN 0951-3590

Carmignani, L. O.; Pedro, A. O.; Costa-Paiva, L. H. \& Pinto-Neto, A. M. (2010). The effect of dietary soy supplementation compared to estrogen and placebo on menopausal symptoms: a randomized controlled trial. Maturitas, Vol.67, No.3, (November 2010), pp. 262-9, ISSN 1873-4111

Carpentier, Y. A.; Portois, L. \& Malaisse, W. J. (2006). n-3 fatty acids and the metabolic syndrome. The American Journal of Clinical Nutrition, Vol. 83, S.6, (May 2006), pp. 1499S-1504S, ISSN 1938-3207

Carrara, V. S.; Amato, A. A.; Neves, F. A. R.; Bazotte, R. B.; Mandarino, J. M. G.; Nakamura, C. V.; Filho, B. P. D. \& Cortez, D. A. G. (2009). Effects of a methanolic fraction of soybean seeds on the transcriptional activity of peroxisome proliferator-activated receptors (PPAR). Brazilian Journal of Medical and Biological Research, Vol.42, No.6, (June 2009), pp. 545-550, ISSN 0100879X

Carrão-Panizzi, M. C.; Favoni, S. P. G. \& Kikuchi, A. (2002). Extraction time for soybean isoflavone determination. Brazilian Archives of Biology and Technology, Vol.45, No.4, (2002), pp.515-518, ISSN 15168913

Cederroth, C. R. \& Nef, S. (2009). Soy, phytoestrogens and metabolism: A review. Molecular and Cellular Endocrinology, Vol.304, No.1-2, (May 2009), pp. 30-42, ISSN 1872-8057

Chandalia, M.; Garg, A.; Lutjohann, D.; Von Bergmann, K.; Grundy, S. M. \& Brinkley, L. J. (2000). Beneficial effects of high dietary fiber intake in patients with type 2 Diabetes Mellitus. The New England of journal of medicine, Vol.342, No.19, (May 2000), pp. 342:1392-1398, ISSN 00284793

Chandrashekar, P.; Lokesh, B. R. \& Gopala Krishna, A. G. (2010). Hypolipidemic effect of blends of coconut oil with soybean oil or sunflower oil in experimental rats. Food Chemistry, Vol.123, No.3, (December 2010), pp. 728-733, ISSN 0308-8146

Chedraui, P.; San Miguel, G. \& Schwager, G. (2010). The effect of soy-derived isoflavones over hot flushes, menopausal symptoms and mood in climacteric women with increased body mass index. Gynecological Endocrinology, (June 2010), in press, ISSN 1473-0766

Chen, W.; Duizer, L.; Corredig, M. \& Goff, H. D. (2010). Addition of soluble soybean polysaccharides to dairy products as a source of dietary fiber. Journal of Food Science, Vol.75, No.6, (August 2010), pp. 478-84, ISSN 0022-1147

Cho, Y.A.; Kim, J.; Park, K.S.; Lim, S.Y.; Shin, A.; Sung, M.K. \& Ro, J. (2010). Effect of dietary soy intake on breast cancer risk according to menopause and hormone receptor status. European journal of clinical nutrition,Vol.64, No.9, (September 2010), pp. 92432, ISSN 1476-5640 
Chung, T. K. H.; Yip, S. K.; Lam, P.; Chang, A. M. Z. \& Haines, C. J. (1996). A randomized, double-blind, placebo-controlled, crossover study on the effect of oral estradiol on acute menopausal symptoms. Maturitas, Vol 25, No.2, (October 1996), pp. 115-123, ISSN 1873-4111

Ciabotti, S.; Barcellos, M. F. P.; Mandarino, J. M. G. \& Tarone, A. G. (2006). Chemical and biochemical evaluation of grains, soymilk and tofus of normal soybean and Lipoxygenase-free soybeans. Ciência e Agrotecnologia, Vol.30, No.5, (October 2006), pp. 920-929, ISSN 1413-7054

Craig, W. J. \& Mangels, A. R. (2009). American Dietetic Association. Position of the American Dietetic Association: vegetarian diets. Journal of the American Dietetic Association, Vol.109, No.7, (July 2009), pp. 1266-82, ISSN 00028223

Crittenden, R. G. \& Playne, M. J. (1996). Production, properties and applications of foodgrade oligosaccharides. Trends in Food Science \& Technology, Vol.7, No.11, (November 1996), pp. 353-361, ISSN 0924-2244

De Leo, F.; Panarese, S.; Gallerani, R. \& Ceci, L. R. (2009). Angiotensin converting enzyme (ACE) inhibitory peptides: production and implementation of functional food. Current pharmaceutical design, Vol.15, No.31, (December 2009), pp. 3622-43, ISSN 1381-6128

Dong, J. Y. \& Qin, L. Q. (2011). Soy isoflavones consumption and risk of breast cancer incidence or recurrence: a meta-analysis of prospective studies. Breast Cancer Research and Treatment, Vol.125, No.2, (January 2011), pp. 315-23, ISSN 0167-6806

Dupont, C.; Chouraqui, J. P.; de Boissieu, D.; Bocquet, A.; Bresson, J. L.; Briend, A.; Darmaun, D.; Frelut, M. L.; Ghisolfi, J.; Girardet, J. P.; Goulet, O.; Hankard, R.; Rieu, D.; Rigo, J.; Vidailhet, M. \& Turck, D. (2010). Comité de nutrition de la Société française de pédiatrie. Dietetic treatment of cow's milk protein allergy. Archives de Pediatrie, (November 2010), in press, ISSN 0096-6630

Endres, J. G. (Month 2001). Soy protein products: characteristics, nutritional aspects and utilization (edition). Libray of Congress, AOCS Press ISBN 1-893997-27-8. United States of America

(http:/ / books.google.com.br/books?hl=ptBR\&lr=\&id=3RNa1vS0sZYC\&oi=fnd\&p $\mathrm{g}=\mathrm{PR} 5 \& \mathrm{dq}=$ Soy+protein + products + characteristics, + nutritional+aspects+and+utiliz ation\&ots=r5evi_iCW7\&sig=-mkmRHmHwnh1aD1 wmHslxcfYzEA\# $\mathrm{v}=$ onepage\&q\&f=false).

Engel, R. R.; Satzger, W.; Günther, W.; Kathmann, N.; Bove, D.; Gerke, S.; Münch, U. \& Hippius, H. Double-blind cross-over study of phosphatidyl-serine vs. placebo in patients with early dementia of Alzheimer type. European Neuropsychopharmacology, Vol.2 , No.2 (June 1992), pp. 149-155, ISSN 1873-7862

Espinosa-Martos, I. \& Rupérez, P. (2006). Soybean oligosaccharides. Potencial as new ingredients in functional food. Nutricion Hospitalaria,Vol.21, No.1, (January 2006), pp. 92-6, ISSN 0212-1611

Ferdowsian, H. R. \& Barnard, N. D. (2009). Effects of plant-based diets on plasma lipids. The American Journal of Cardiology,Vol.104, No.7, (October 2009), pp. 947-56, ISSN 00029149

Fernández-San, J. P. M. (2009). Trans fatty acids (tFA): sources and intake levels, biological effects and content in commercial Spanish food/ Ácidos grasos trans (AGt): fuentes y niveles de ingesta, efectos biológicos y contenido en los alimentos comerciales 
españoles. Nutricion Hospitalaria, Vol.24, No.5, (September 2009), pp. 515-520, ISSN 0212-1611

Friedman, M. \& Brandon, D. L. (2001). Nutritional and health benefits of soy proteins. Journal of Agricultural and Food Chemistry, Vol.49, No.3, (March 2001), pp. 1069-1086, ISSN 1520-5118

Food and Drug Administration (FDA). FDA approves new health claim for soybean protein and coronary heart disease. FDA Talk Paper 1999, in www.fda.gov.

Galleano, M.; Pechanova, O. \& Fraga, C. G. (2010). Hypertension, nitric oxide, oxidants, and dietary plant polyphenols. Current Pharmaceutical Biotechnology, Vol.11, No.8, (December 2010), pp. 837-48, ISSN 1389-2010

Genovese, M. I.; Davila, J. \& Lajolo, F. M. (2006). Isoflavones in processed soybean products from Ecuador. Brazilian Archives of Biology and Technology, Vol.49, No.5, (September 2006), pp. 853-859, ISSN 1516-8913

Gesteira, A. S.; Schuster, I.; José, I. C.; Piovesan, N. D.; Viana, J. M. S.; Barros, E. G. \& Moreira M. A . (2003). Biometrical analyses of linolenic acid content of soybean seeds. Genetics and Molecular Biology. Vol.26, No.1 (September 2003), pp. 65-68, ISSN $1415-4757$

Ghosh, D. \& Scheepens, A. (2009). Vascular action of polyphenols. Molecular Nutrition and food research, Vol.53, No.3, (March 2009), pp. 322-31, ISSN 1613-4133

Gimenez, I.; Martinez, R. M.; Lou, M.; Mayoral, J. A.; Garay, R. P. \& Alda, J. O. (1998). Saliuretic action by genistein in the isolated, perfused rat kidney. Hypertension, Vol.31, No.2, (February 1998), pp. 706-11, ISSN 0194911X

Greaves, K. A.; Parks, J. S.; Williams, J. K. \& Wagner, J. D. (1999). Intact dietary soy protein, but not adding an isoflavone-rich soy extract to casein, improves plasma lipids in ovariectomized cynomolgus monkeys. Journal of Nutrition, Vol.129, No.8, (August 1999), pp. 1585-1592, ISSN 0022-3166

Hachul, H.; Brandão, L. C.; D'Almeida, V.; Bittencourt, L. R.; Baracat, E. C. \& Tufik, S. (2010) Isoflavones decrease insomnia in postmenopause. Menopause, (August 2010), in press, ISSN 1530-0374

Harper, C. R. \& Jacobson, T. A. (2001). The Fats of Life - The Role of Omega-3 Fatty Acids in the Prevention of Coronary Heart Disease. Archives of Internal Medicine, Vol.8, No.61, (October 2001), pp. 2185-2192, ISSN 1538-3679

Hermann, M.; Flammer, A. \& Lüscher, T. F. (2006). Nitric oxide in hypertension. Journal of Clinical Hypertension, Vol.8, No.12, (May 2006), pp. 17-29, ISSN 1938-3207

Hirayama, F.; Lee, A. H.; Binns, C. W.; Hiramatsu, N.; Mori, M. \& Nishimura, K. (2010).Dietary intake of isoflavones and polyunsaturated fatty acids associated with lung function, breathlessness and the prevalence of chronic obstructive pulmonary disease: Possible protective effect of traditional Japanese diet. Molecular Nutrition and food research,Vol.54, No.7, (July 2010), pp. 909-17, ISSN 1613-4133

Holguin, F.; Téllez-Rojo, M. M.; Lazo, M.; Mannino, D.; Schwartz, J.; Hernández, M. \& Romieu, I. (2004). Cardiac Autonomic Changes Associated With Fish Oil vs Soy Oil Supplementation in the Elderly. Chest Journal, Vol.127, No.4, (April 2004), pp. 11021107, ISSN 1931-3543

Hooshmand, S.; Juma, S. \& Arjmandi, B. H. (2010). Combination of genistin and fructooligosaccharides prevents bone loss in ovarian hormone deficiency. Journal of medicinal food, Vol.13, No.2, (April 2010), pp. 320-5, ISSN 1557-7600 
Huisman, M. M. H. (2000). Elucidation of the chemical fine structure of polysaccharides from soybean and maize kernel cell walls. PhDthesis, Wageningen University, (March, 2000), ISBN 9058081877, Wageningen, Netherlands

Hunter, J. E.; Zhang, J. \& Kris-Etherton, P. M. (2010). Cardiovascular disease risk of dietary stearic acid compared with trans, other saturated, and unsaturated fatty acids: a systematic review. American Journal of Clinical Nutrition, Vol.91, No.1, (January 2010), pp. 46-63, ISSN 1938-3207

Jasentuliyana, N.; Toma, R. B.; Klavons, J. A. \& Medora, N. (1998). Beverage cloud stability with isolated soy protein. Journal of the Science of Food and Agriculture, Vol.78, No.3, (November 1998), pp. 389-394, ISSN 1097-0010

Jequier, E. (2002). Pathways to obesity. International journal of obesity and related metabolic disorders, Vol.26, No.6, (September 2002), pp. 12-7, ISSN 0307-0565

Jenkins, D. J. A.; Kendall, C. W. C.; Marchie, A Alexandra L Jenkins, A. L.; Augustin, L. S. A.; Ludwig, D. S.; Barnard, N. D. \& Anderson, J. W. (2003). Type 2 diabetes and vegetarian diet. American journal of clinical nutrition, Vol.78 No.3, (September 2003), pp. 610-616, ISSN 1938-3207

Jenkins, D. J.; Kendall, C. W.; Jackson, C. J.; Connelly, P. W.; Parker, T.; Faulkner, D.; Vidgen, E.; Cunnane, S. C.; Leiter, L. A. \& Josse, R. G. (2002). Effects of high- and lowisoflavone soyfoods on blood lipids, oxidized LDL, homocysteine, and blood pressure in hyperlipidemic men and women. American journal of clinical nutrition, Vol.76, No2., (August 2002), pp. 365-372, ISSN 1938-3207

Jiménez-Escrig, A.; Tenorio, M. D.; Espinosa-Martos, I. \& Rupérez, P. (2008). Healthpromoting effects of a dietary fiber concentrate from the soybean byproduct okara in rats. Journal of agricultural of food chemistry, Vol.56, No.16, (August 2008), pp. 7495-501, ISSN 1520-5118

Kang, J.; Badger, T. M.; Ronis, M. J. \& Wu, X. (2010). Non-isoflavone phytochemicals in soy and their health effects. Journal of agricultural of food chemistry, Vol.58, No.14, (July 2010), pp. 8119-33, ISSN 1520-5118

Kang, X.; Zhang, Q.; Wang, S.; Huang, X. \& Jin, S. (2010). Effect of soy isoflavones on breast cancer recurrence and death for patients receiving adjuvant endocrine therapy. Canadian Medical Association Journal, Vol.182, No.17, (November 2010), pp. 1857-62, ISSN 0820-3946

Kato-Kataoka, A.; Sakai, M.; Ebina, R.; Nonaka, C.; Asano, T. \& Miyamori T. (2010). Soybean-derived phosphatidylserine improves memory function of the elderly Japanese subjects with memory complaints. Journal of Clinical Biochemistry and Nutrition. Vol.47, No.3, (November 2010), pp. 246-55, ISSN 1880-5086

Kelley, D. S. (2001). Modulation of human immune and inflammatory responses by dietary fatty acids. Nutrition, Vol.17, No.7, (July 2001), pp. 669-673, ISSN 18731244Kreijkamp-Kaspers, S.; Kok, L.; Grobbee, D. E.; de Haan, E. H.; Aleman, A.; Lampe, J. W. \& van der Schouw, Y. T. (2004). Effect of soy protein containing isoflavones on cognitive function, bone mineral density, and plasma lipids in postmenopausal women: a randomized controlled trial. JAMA: the journal of the American Medical Association, Vol.292, No.1, (July 2004), pp. 65-74, ISSN 1538-3598

Kris-Etherton, P. M.; Harris, W. S.; Lawrence J. Appel, L. J. (2003). Fish Consumption, Fish Oil, Omega-3 Fatty Acids, and Cardiovascular Disease. Arteriosclerosis, Thrombosis, and Vascular Biology, Vol.23, No.2, (February 2003), pp. e-20-e-30, ISSN 10795642 
Lattrich, C.; Lubig, J.; Springwald, A.; Goerse, R.; Ortmann, O. \& Treeck, O. (2010). Additive effects of trastuzumab and genistein on human breast cancer cells. Anticancer Drugs, (December 2010), in press, ISSN 1473-5741

Lemke S. L.; Vicini, J. L.; Su, H.; Goldstein, D. A.; Nemeth, M. A.; Krul, E. S. \& Harris, W. S. (2010). Dietary intake of stearidonic acid-enriched soybean oil increases the omega3 index: randomized, double-blind clinical study of efficacy and safety. American journal of clinical nutrition, Vol.92, No.4, (October 2010), pp. 766-75, ISSN 1938-3207

Lerman, R. H.; Minich, D. M.; Darland, G.; Lamb, J. J.; Chang, J. L.; Hsi, A.; Bland, J. S. \& Tripp, M. L. (2010). Subjects with elevated LDL cholesterol and metabolic syndrome benefit from supplementation with soy protein, phytosterols, hops rho iso-alpha acids, and Acacia nilotica proanthocyanidins. Journal of Clinical Lipidology, Vol.4, No.1, (January-February 2010), pp. 59-68, ISSN 1933-2874

Liss, M. A.; Schlicht, M.; Kahler, A.; Fitzgerald, R.; Thomassi, T.; Degueme, A.; Hessner, M. \& Datta, M. W. (2010). Characterization of soy-based changes in Wnt-frizzled signaling in prostate cancer. Cancer Genomics Proteomics, Vol.7, No.5, (SeptemberOctober 2010), pp. 245-52, ISSN 1790-6295

Lissin, L. W. \& Cooke, J. P. (2000). Phytoestrogens and cardiovascular health. Journal of the American College of Cardiology, Vol.35, No.6, (May 2000), pp.1403-1410, ISSN 15583597

Liu, K. (1997). Soybeans chemistry technology and utilization. 2.ed. New York: Chapman \& Hall. 532p. http://www.scielo.br/scieloOrg/php/reflinks.php?refpid=S0100204X200700120001600010\&pid=S0100-204X2007001200016\&lng=en.

Liu, K. S. (1999). Chemistry and nutritional value of soybean components. In Soybeans: Chemistry, Technology and Utilization. Aspen Publ. Inc, pp. 25-113, ISBN 0834212994

Lukaczer, D.; Liska, D. J.; Lerman, R. H., Darland, G.; Schiltz, B.; Tripp, M. \& Bland, J. S. (2006). Effect of a low glycemic index diet with soybean protein and phytosterols on CVD risk factors in postmenopausal women. Nutrition, Vol.22, No.2, (February 2006), pp. 104-113, ISSN 1873-1244

Lund, T.; Mangsbo, S.M.; Scholz, H.; Gjorstrup, P.; Tötterman, T.H.; Korsgren, O.; Foss, A. (2010). Resolvin E1 reduces proinflammatory markers in human pancreatic islets in vitro. Experimental and Clinical Endocrinology \& Diabetes, Vol.118, No.4, (April 2010), PP.237-44, ISSN 1439-3646

Macedo-Silva, A.; Shimokomaki, M.; Vaz, A. J.; Yamamoto, Y. Y. \& Tenuta-Filho, A. (2001). Textured Soy Protein Quantification in Commercial Hamburger . Journal of Food Composition and Analysis, Vol.14, No.5, (October 2001), pp. 469-478, ISSN 0889-1575

Maki, K. C.; Butteiger, D. N.; Rains, T. M.; Lawless, A.; Reeves, M. S.; Schasteen, C. \& Krul, E. S. (2010). Effects of soy protein on lipoprotein lipids and fecal bile acid excretion in men and women with moderate hypercholesterolemia. Journal of Clinical Lipidology, Vol.4, No.6, (November-December 2010), pp. 531-42, ISSN 1933-2874

Martínez Augustin, O. \& Martínez de Victoria, E. (2006). Proteins and peptides in enteral nutrition. Nutricion Hospitalaria,Vol.21, Suppl 2:, (November 2006), pp. 01-14, ISSN 0212-1611

Martin, C. A.; Visentainer, J. V.; Oliveira, A. N.; Oliveira, C. C.; Matsushita, M. \& Souza, N. E. (2008). Fatty acid contents of Brazilian soybean oils with emphasis on trans fatty 
acids. Journal of the Brazilian Chemical Society, Vol.19, No.1, (2008), pp.117-122, ISSN: 0103-5053

Martin, D.; Song, J.; Mark, C. \& Eyster, K. (2008). Understanding the cardiovascular actions of soy isoflavones: potential novel targets for antihypertensive drug development. Cardiovascular $\mathcal{E}$ hematological disorders drug targets, Vol.8, No.4, (December 2008), pp. 297-312, ISSN 1871-529X

Martins, R. T.; Cascabulho, A. R.; Baião, N. C. \& Afonso, R. J. C. F. (2003). Effect of different soybean oils on fatty acids composition of broiler carcass. Arquivo Brasileiro de Medicina Veterinária e Zootecnia, Vol.55, No.1, (February 2003), pp. 92-98, ISSN 01020935

Mateos-Aparicio, I.; Cuenca, A. R.; Villanueva-Soares, M. J. \& Zapata-Revilla, M. A. (2008). Soybean, a promising health source. Nutricion Hospitalaria, Vol.23, No.4, (August, 2008), pp. 305-312, ISSN 0212-1611

Merz-Demlow, B. E.; Duncan, A. M.; Wangen, K. E.; Xu, X.; Carr, T. P.; Phipps, W. R. \& Kurzer, M. S. (2000). Soy isoflavones improve plasma lipids in normocholesterolemic, premenopausal women. American journal of clinical nutrition, Vol.71, No.6, (June 2000), pp. 1462-1469., ISSN 1938-3207

Mesa, N. J. E.; Alavi, S.; Singh, N.; Shi, Y. C.; Dogan, H. \& Sang, Y. (2009). Soy proteinfortified expanded extrudates: Baseline study using normal corn starch. Journal of Food Engineering, Vol.90, No.2, (January 2009), pp. 262-270, ISSN 0260-8774

Messina, M. J. (1997). Soybeanfoods: their role in disease prevention and treatment. In Soybeans: Chemistry, Technology and Utilization. Aspen Publicashion, p. 442-447, ISBN 0834212994

Messina, M. (2010). Insights Gained from 20 Years of Soy Research. The journal of nutrition, Vol.140, No.12, (December 2010), pp. 2289S-2295S, ISSN 1541-6100

Mikkola,T. S.; Anthony, M. S.; Clarkson, T. B. \& St. Clair, R. W. (2003). Serum cholesterol efflux potential is an independent predictor of coronary artery atherosclerosis. Atherosclerosis, Vol.170, No.1, (September 2003), pp.31-38, ISSN 1879-1484

Miura, E. M. Y.; Binotti, M. A. R.; Camargo, D. S.; Mizubutti, I. Y. \& Ida, E. I. (2001). Avaliação biológica da soja com baixas atividades de inibidores de tripsina e ausência do inibidor Kunitz. Archivos Latinoamericanos de Nutrición, Vol.51, No.2, (June 2001), pp.195-198, ISSN 0004-0622

Monteiro, M. R. P.; Moreira, M. A.; Costa, N. M. B.; Oliveira, M. G. \& Pires, C. V. (2003). Avaliação da digestibilidade protéica de genótipos de soja com ausência e presença do inibidor de tripsina Kunitz e lipoxigenases. Brazilian Journal of Food Technology, Vol.32, No.4, (July-August, 2003), pp. 99-107, ISSN 0004-0622

Moreno-Aliaga, M. J.; Lorente-Cebrián, S. \& Martínez, J. A. (2010). Regulation of adipokine secretion by n-3 fatty acids. The Proceedings of the Nutrition Society. Vol.69, No.3, pp. 324-34, ISSN 0029-6651

Mori, T. A. (2010). Omega-3 fatty acids and blood pressure. Cellular and Molecular Biology, Vol.56, No.1, pp. 83-92, ISSN 1165-158X

Moughan, P. J. (2003). Amino acid availability: aspects of chemical analysis and bioassay methodology. Nutrition Research Reviews, Vol.16, No.2, (December 2003), pp.127141, ISSN 1475-2700 
Nagarajan, S. (2010). Mechanisms of anti-atherosclerotic functions of soy-based diets. The journal of nutritional biochemistry, Vol.21, No.4, (April 2010), pp. 255-60, ISSN 15416100

Nikander, E.; Tiitinen, A.; Laitinen, K.; Tikkanen, M. \& Ylikorkala, O. (2004). Effects of isolated isoflavonoids on lipids, lipoproteins, insulin sensitivity, and ghrelin in postmenopausal women. The Journal of clinical endocrinology and metabolism. Vol.89, No.7, (July 2004), pp. 3567-3572, ISSN 1945-7197

Nilsson, S. \& Gustafsson, J. A. (2002). Biological role of estrogen and estrogen receptors. Critical Reviews in Biochemistry and Molecular Biology, Vol.37, No.1, (2002), pp. 1-28, ISSN 1040-9238

Nyby, M. D.; Abedi, K.; Eslami, P.; Hernandez, G.; Smutko, V.; Berger, M. E. \& Tuck, M. L. (2004). Dietary fish oil prevents hypertension, oxidative stress and suppression of endothelial nitric oxide synthase expression in fructose-fed rats. American Journal of Hypertensive, Vol.17, S.1, (May 2004), pp. 216A. ISSN 1879-1905

Oddens, B. M. (1994). The climacteric cross-culturally: The International Health Foundation South-east Asia Study. Maturitas, Vol.19, No.3, (October 1994), pp. 155-156, ISSN 1873-4111

Oomen, C.; Ocké, M. C.; Feskens, E. J.; Van Erp-Baart, M. A. J.; Kok, F. J. \& Kromhout, D. (2001). Association between trans fatty acids intake and 10-year risk of coronary heart disease in the Zutphen Elderly Study: a prospective population-based study. Lancet, Vol.357, No.9258, (March 2001), pp.746-751, ISSN 1474-547X

Onuegbu, A. J.; Olisekodiaka, J. M.; Onibon, M. O.; Adesiyan, A. A. \& Igbeneghu, C. A. (2011). Consumption of Soymilk Lowers Atherogenic Lipid Fraction in Healthy Individuals. Journal of Medicinal Food, (January 2011), pp. 1-4, in press, ISSN 15577600 .

Paddon-Jones, D.; Westman, E.; Mattes, R. D.; Wolfe, R. R.; Astrup, A. \& WesterterpPlantenga, M. (2008). Protein, weight management, and satiety. American journal of clinical nutrition, Vol.87, No.5, (May 2008), pp. 1558-1561, ISSN 1938-3207

Pavese, J. M.; Farmer, R. L. \& Bergan, R. C. (2010). Inhibition of cancer cell invasion and metastasis by genistein. Cancer Metastasis Reviews., Vol.19, No.3, (September 2010), pp. 465-82, ISSN 1573-7233

Perut, F.; Montufar, E. B.; Ciapetti, G.; Santin, M.; Salvage, J.; Traykova, T.; Planell, J. A.; Ginebra, M. P. \& Baldini, N. (2010). Novel soybean/gelatine-based bioactive and injectable hydroxyapatite foam: material properties and cell response. Acta Biomaterialia, (December 2010), in press, ISSN 1878-7568

Persson, C.G.; Uller, L. (2010). Resolution of cell-mediated airways diseases. Respiratory Research, Vol.11, No.75 (June 2011), pp.1-12. ISSN 1465-993X

Priolii, R. H. G.; Mendes Junior, C. T.; Arantes, N. E. \& Contel, E. P. B. (2002). Characterization of brazilian soybean cultivars using microsatellite markers. Genetics and molecular biology, Vol.25, No.2, (June 2002), ISSN 1415-4757

Rajasree, C. R.; Rajmohan, T. \& Augusti, K. T. (2009). Antiatherogenic and antiperoxidative effects of garlic and soy proteins in alcohol fed rats. Indian Journal of Experimental Biology, Vol.47, No.3, (March 2009), pp. 169-75, ISSN 0975-1009

Reynolds, K.; Chin, A.; Lees, K. A.; Nguyen, A.; Bujnowski, D. \& He, J. (2006). A MetaAnalysis of the Effect of Soybean Protein Supplementation on Serum Lipids. The 
American journal of cardiology, Vol.98, No.5, (September 2006), pp. 633-640, ISSN 00029149

Redondo-Cuenca, A.; Villanueva-Suárez, M. J.; Rodríguez-Sevilla, M. D. \& Mateos-Aparicio, I. (2007). Chemical composition and dietary fibre of yellow and green commercial soybeans (Glycine max). Food Chemistry, Vol.101, No.3, (March 2007), pp. 1216-1222, ISSN 0308-8146

Riaz, M. N. (1999). Soybeans as Functional Foods. Cereal Foods World, Vol.44, No.2, (February 1999), pp. 89-92, ISSN 0146-6283

Ricketts, M. L.; Moore, D. D.; Banz, W. J.; Mezei, O. \& Shay, N. F. (2005). Molecular mechanisms of action of the soy isoflavones includes activation of promiscuous nuclear receptors. A review. The Journal of nutritional biochemistry, Vol.16, No.6, (June 2005), pp. 321-330, ISSN 1873-4847

Richter, Y.; Herzog, Y.; Cohen, T. \& Steinhart, Y. (2010). The effect of phosphatidylserinecontaining omega-3 fatty acids on memory abilities in subjects with subjective memory complaints: a pilot study. Clinical Interventions in aging, Vol.2, No.5, (November 2010), pp. 313-6, ISSN 1176-9092

Ryan-Borchers, T.A.; Park, J.S.; Chew, B.P.; McGuire, M.K.; Fournier, L.R.; Beerman, K.A. (2006). Soy isoflavones modulate immune function in healthy postmenopausal women. American Journal of Clinical Nutrition, Vol. 83, No.5, (May 2006), pp.111825, ISSN 1938-3207

Sacks, M.; Sacks, M. D.; Lichtenstein, A. D. S.; Van Horn,L.; Harris, W.; Kris-Etherton, P. \& Winston, M. (2006). Soy Protein, Isoflavones, and Cardiovascular Health. Circulation, Vol.113, No.7, (February 2006), pp. 1034-1044, ISSN 1524-4539

Sagara, M.; Kanda, T.; NJelekera, M.; Teramoto, Y.; Armitage, L.; Birt, N.; Birt, C. \& Yamori, Y. (2004). Effects of Dietary Intake of Soy Protein and Isoflavones on Cardiovascular Disease Risk Factors in High Risk, Middle-Aged Men in Scotland. Journal of the American College of Nutrition, Vol.23, No.1, (February 2004), pp. 85-91, ISSN 1541-1087

Scheppach, W.; Luethrs, H.; Melcher, R.; Gostner, A.; Schauber, J.; Kudlich, T.; Weiler, F. \& Menzel, T. (2004). Antiinflammatory and anticarcinogenic effects of dietary fibre. Clinical nutrition supplements, Vol.1, No.2, (February 2004), pp. 51-58, ISSN 17441161

Seki, H.; Fukunaga, K.; Arita, M.; Arai, H.; Nakanishi, H.; Taguchi, R.; Miyasho, T.; Takamiya, R.; Asano, K.; Ishizaka, A.; Takeda, J.; Levy, B.D. (2010). The antiinflammatory and proresolving mediator resolvin E1 protects mice from bacterial pneumonia and acute lung injury. The Journal of Immunology, Vol.184, No.2, (June 2010), pp.836-43, ISSN 1550-6606.

Setchell, K. D. R. \& Cassidy, A. (1999). Dietary isoflavones: Biological effects and relevance to human health. The journal of nutrition, Vol.129, No.3, (March 1999), pp.758-767, ISSN 1541-6100

Simão, A. N.; Lozovoy, M. A.; Simão, T. N.; Dichi, J. B.; Matsuo, T. \& Dichi, I. (2010). Nitric oxide enhancement and blood pressure decrease in patients with metabolic syndrome using soy protein or fish oil. Arquivos Brasileiros de Endocrinologia e Metabologia, Vol.54, No.6, (August 2010), pp. 540-5, ISSN 1677-9487 
Soares L. L.; Lucas, A. M. M. \& Boaventura, G. T. (2005). Can organic and transgenic soy be used as a substitute for animal protein by rats? Brazilian journal of medical and biological research, Vol.38, No.4, (April 2005), pp.583-586, ISSN 0100879X

Shukla, S. K.; Gupta, S.; Ojha, S. K. \& Sharma, S. B. (2010). Cardiovascular friendly natural products: a promising approach in the management of CVD. Natural Product Research, Vol.27, No.9, (May 2010), pp. 873-98, ISSN 1478-6427

Singh, P.; Kumar, R.; Sabapathy, S. N. \& Bawa, A. S. (2008). Functional and Edible Uses of Soy Protein Products. Comprehensive Reviews in Food Science and Food Safety, Vol.7, No.1, (January 2008), pp. 14-28, ISSN 1541-4337

Sosulski, F. W.; Elkowicz, L. \& Reichert, R. D. (1982). Oligosaccharides in eleven legumes and their air-classified protein and starch fractions. Journal of Food Science, Vol.47, No.2, (March 1982), pp. 498-502, ISSN 0022-1147

Tacyildiz, N.; Ozyoruk, D.; Yavuz, G.; Unal, E.; Dincaslan, H.; Dogu, F.; Sahin, K. \& Kucuk, O. (2010). Soy isoflavones ameliorate the adverse effects of chemotherapy in children. Nutrition and Cancer, Vol.62, No.7. (October 2010), pp.1001-5, ISSN 15327914

Taku, K.; Melby, M. K.; Takebayashi, J.; Mizuno, S.; Ishimi, Y.; Omori, T. \& Watanabe, S. (2010). Effect of soy isoflavone extract supplements on bone mineral density in menopausal women: meta-analysis of randomized controlled trials. Asia Pacific journal of Clinical Nutrition, Vol.19, No.1, (March 2010), pp. 33-42, ISSN 1440-6047

Taku, K.; Umegaki, K.; Sato, Y.; Taki, Y.; Endoh, K. \& Watanabe, S. (2007). Soy isoflavones lower serum total and LDL cholesterol in humans: a meta-analysis of 11 randomized controlled trials. American Journal of Clinical Nutrition, Vol.85, No.4, (April 2007), pp. 1148-56, ISSN 1938-3207

Taylor, S. L. \& Kabourek, J. L.(2003). Soyfoods and allergies: separating fact from fiction. The Soy Connection, Vol.11, No.2. http://www.soyconnection.com/upload/SCNv11n2.pdf

Tomomatsu, H. (1994). Health effects of oligosaccharides. Food Technology, Vol.61, No.5, (October 1994), pp. 61-65, ISSN 0737-3937

Torrezan, R.; Gomes, R. M.; Ferrarese, M. L.; Melo, F. B.; Ramos, A. M. D.; Mathias, P. C. F. \& Scomparin, D. X. (2008). Treatment with isoflavones replaces estradiol effect on the tissue fat accumulation from ovariectomized rats. Arquivos Brasileiros de Endocrinologia e Metabologia, Vol.52, No.9, (December 2008), pp. 1489-1496, ISSN 1677-9487

Torre-Villalvazo, I.; Gonzalez, F.; Aguilar-Salinas, C. A.; Tovar, A. R. \& Torres, N. (2009). Dietary soy protein reduces cardiac lipid accumulation and the ceramide concentration in high-fat diet-fed rats and ob/ob mice. The journal of Nutrition, Vol.139, No.12, (December 2009), pp. 237-43, ISSN 1541-6100

Torres y Torres, N.; Palacios-González, B.; Noriega-López, L. \& Tovar-Palacio, A. R. (2006). Índice glicémico, índice insulinémico y carga glicémica de bebidas de soya con un contenido bajo y alto en hidratos de carbono/ Glycemic, insulinemic index, glycemic load of soy beverage with low and high content of carbohydrates. Revista de investigación clínica, Vol.58, No.5, (October 2006), pp. 487-497, ISSN 0034-8376

Trevisan, M. C.; Souza, J. M. \& Marucci, M. D. (2010). Influence of soy protein and exercises with weights on the resting energy expenditure of women in post-menopause. 
Revista da Associação Medica Brasileira, Vol.56, No.5, (2010), pp. 572-578, ISSN 15187365

Tull, S.P.; Yates, C.M.; Maskrey, B.H.; O'Donnell, V.B.; Madden, J.; Grimble, R.F.; Calder, P.C.; Nash, G.B.; Rainger, G.E. (2009) Omega-3 Fatty acids and inflammation: novel interactions reveal a new step in neutrophil recruitment. PLoS Biology, Vol.7, No.8, (August 2009). ISSN1545-7885

Ullah, M. F.; Ahmad, A.; Zubair, H.; Khan, H. Y.; Wang, Z.; Sarkar, F. H. \& Hadi, S. M. (2010). Soy isoflavone genistein induces cell death in breast cancer cells through mobilization of endogenous copper ions and generation of reactive oxygen species. Molecular Nutrition \& Food Research, (December 2010), in press, ISSN 1613-4133

Vakhapova, V.; Cohen, T.; Richter, Y.; Herzog, Y. \& Korczyn, A. D. (2010). Phosphatidylserine containing omega-3 fatty acids may improve memory abilities in non-demented elderly with memory complaints: a double-blind placebocontrolled trial. Dementia and Geriatric Cognitive Disorders, Vol.29, No.5, (June 2010), pp. 467-74, ISSN 1420-8008.

Valenzuela, A. \& Morgado, N. (1999). Trans fatty acids isomersin human health and in the food industry. Biological Research, Vol.32, No.4, (1999), pp. 273-287, ISSN 0717-6287

Vitolins, M. Z.; Case, L. D.; Morgan, T. M.; Miller, M. A. \& Burke, G. L. (2010). Soy use and vasomotor symptoms: Soy Estrogen Alternative follow-up study. International Journal of Women's Health, Vol.2, No.2, (November 2010), pp. 381-6, ISSN 1179-1411

Wangen, K. E.; Duncan, A. M.; Xu, X. \& Kurzer, M. S. (2001). Soy isoflavones improve plasma lipids in normocholesterolemic and mildly hypercholesterolemic postmenopausal women. American journal of clinical nutrition, Vol.73, No.2, (February 2001), pp. 225-231, ISSN 1938-3207

Wilcox, J. R.; \& Shibles, R. M. (2001). Interrelationships among seed quality attributes in soybean. Crop Science, Vol.41, No.1, (January-February 2001), pp. 11-14, ISSN 1439037X

Wong, J. M.; Kendall, C. W.; Souza, R.; Emam, A.; Marchie, A.; Vidgen, E.; Holmes, C. \& Jenkins, D. J. (2010). The effect on the blood lipid profile of soy foods combined with a prebiotic: a randomized controlled trial. Metabolism: clinical and experimental, Vol.59, No.9, (September 2010), pp. 1331-40, ISSN 0026-0495

Woodman, R. J.; Mori, T. A.; Burke, V.; Puddey, I. B.; Watts, G. F. \& Beilin, L. J. (2002). Effects of purified eicosapentaenoic and docosahexaenoic acids on glycemic control, blood pressure, and serum lipids in type 2 diabetic patients with treated hypertension. American Journal of Clinical Nutrition, Vol.76, No.5, (November 2002), pp. 1007-15, ISSN 1938-3207

Xie, Y. R. \& Hettiarachchy, N. S. (1997). Xanthan Gum Effects on Solubility and Emulsification Properties of Soy Protein Isolate. Journal of Food Science, Vol.62, No.6, (November 1997), pp. 1101-1104, ISSN 0022-1147

Xu, S. Z.; Zhong, W.; Ghavideldarestani, M.; Saurabh, R.; Lindow, S. W. \& Atkin, S. L. (2009). Multiple mechanisms of soy isoflavones against oxidative stress-induced endothelium injury. Free Radical Biology \& Medicine, Vol.47, No.2, (July 2009), pp. 167-75, ISSN 1873-4596

Yang, G.; Shu X-O.; Jin, F.; Zhang, X.; Li, H-L.; Li, Q.; Gao, Y-T. \& Zheng, W. (2005). Longitudinal study of soy intake and blood pressure among middle-aged and 
elderly Chinese women. American Journal of Clinical Nutrition, Vol.81, No.5, (May 2005), pp. 1012-7, ISSN 1938-3207

Yao, J. J.; Wei, L. S. \& Steinberg, M. P. (1988). Water-Imbibing Capacity and Rheological Properties of Isolated Soy Proteins. Journal of Food Science, Vol.53, No.2, (March 1988), pp. 464-467, ISSN 0022-1147

Yeo, S. K. \& Liong, M. T. (2010). Effect of prebiotics on viability and growth characteristics of probiotics in soymilk. Journal of the Science of Food and Agriculture, Vol.90, No.2, (January 2010), pp. 267-75, ISSN 1097-0010

Yamori, Y.; Moriguchi, E. H.; Teramoto, T.; Miura, A.; Fukui, Y.; Honda, K.; Fukui, M.; Nara, Y.; Taira, K. \& Moriguchi, Y. (2002). Soybean Isoflavones Reduce Postmenopausal Bone Resorption in Female Japanese Immigrants in Brazil: A Ten-Week Study. Journal of the American College of Nutrition, Vol.21, No.6, (December 2002), pp. 560563, ISSN 1541-1087

Zanotti, A.; Valzelli, L. \& Toffano, G. Chronic phosphatidylserine treatment improves spatial memory and passive avoidance in aged rats. Psychopharmacology, Vol.99, No.3, (1989), pp. 316-321, ISSN 0033-315 


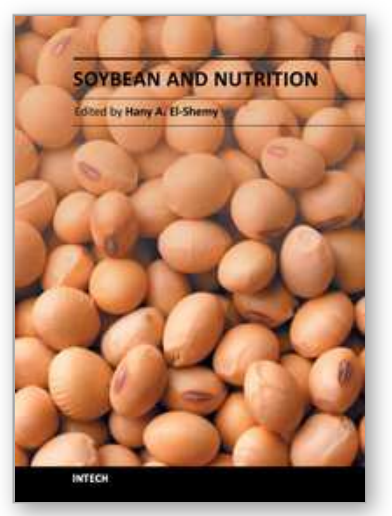

\author{
Soybean and Nutrition \\ Edited by Prof. Hany El-Shemy
}

ISBN 978-953-307-536-5

Hard cover, 476 pages

Publisher InTech

Published online 12, September, 2011

Published in print edition September, 2011

Worldwide, soybean seed proteins represent a major source of amino acids for human and animal nutrition. Soybean seeds are an important and economical source of protein in the diet of many developed and developing countries. Soy is a complete protein and soy-foods are rich in vitamins and minerals. Soybean protein provides all the essential amino acids in the amounts needed for human health. Recent research suggests that soy may also lower risk of prostate, colon and breast cancers as well as osteoporosis and other bone health problems and alleviate hot flashes associated with menopause. This volume is expected to be useful for student, researchers and public who are interested in soybean.

\title{
How to reference
}

In order to correctly reference this scholarly work, feel free to copy and paste the following:

Sandra Maria Barbalho and Flávia, M. V. Farinazzi-Machado (2011). Soybean: Food or Remedy?, Soybean and Nutrition, Prof. Hany El-Shemy (Ed.), ISBN: 978-953-307-536-5, InTech, Available from: http://www.intechopen.com/books/soybean-and-nutrition/soybean-food-or-remedy-

\section{INTECH}

open science | open minds

\section{InTech Europe}

University Campus STeP Ri

Slavka Krautzeka 83/A

51000 Rijeka, Croatia

Phone: +385 (51) 770447

Fax: +385 (51) 686166

www.intechopen.com

\section{InTech China}

Unit 405, Office Block, Hotel Equatorial Shanghai

No.65, Yan An Road (West), Shanghai, 200040, China

中国上海市延安西路65号上海国际贵都大饭店办公楼405单元

Phone: +86-21-62489820

Fax: +86-21-62489821 
(C) 2011 The Author(s). Licensee IntechOpen. This chapter is distributed under the terms of the Creative Commons Attribution-NonCommercialShareAlike-3.0 License, which permits use, distribution and reproduction for non-commercial purposes, provided the original is properly cited and derivative works building on this content are distributed under the same license. 